\begin{tabular}{lc}
\hline \hline $\begin{array}{l}\text { MINING AND METALLURGY INSTITUTE BOR } \\
\text { UDK: } 622\end{array}$ & $\begin{array}{l}\text { ISSN: 2334-8836 (Štampano izdanje) } \\
\text { ISSN: 2406-1395 (Online) }\end{array}$ \\
\hline \hline & DOI:10.5937/MMEB1502149J \\
UDK: 542:66.087:546.76(045)=111 & \\
Bore Jegdić ${ }^{*}$, Maja Stevanović, Aleksandar Jegdic ${ }^{*}$
\end{tabular}

\title{
CHEMICAL AND ELECTROCHEMICAL DISSOLUTION OF CHROMIUM AT ROOM AND ELEVATED TEMPERATURES ${ }^{* *}$
}

\begin{abstract}
The influence of temperature on electrochemical and chemical dissolution of chromium was studied in the acidic sulphuric solutions. The hydrogen evolution reaction, as well as the anodic dissolution and chemical dissolution of chromium from activated surfaces in sulphuric acid solutions $p H 1$ follow the Arrhenius law, with the apparent activation energies of $35 \mathrm{~kJ} \mathrm{~mol}^{-1}, 58 \mathrm{~kJ} \mathrm{~mol}^{-1}$ and $62 \mathrm{~kJ} \mathrm{~mol}^{-1}$, respectively. The higher activation energy of the chemical dissolution of chromium leads to the signifycantly noticeable chemical corrosion on elevated temperatures in comparison with the electrochemical corrosion.
\end{abstract}

Keywords: chromium chemical corrosion, electrochemical dissolution, activation energy

\section{INTRODUCTION}

Simultaneously with the electrochemical dissolution of chromium occurs its chemical dissolution, which does not depend on potential and that, in certain circumstances, is dominant process of dissolution, especially at elevated temperatures [1-9]. Chemical dissolution is the cause of occurrence the hydrogen evolution, which is not subjected to the laws of electrochemical kinetics.

Determination the activation energy of chemical chromium dissolution, electrochemical chromium dissolution, cathodic hydrogen evolution and temperature dependence on electrochemical corrosion rate was determined and analyzed in this paper. Also, texture of chromium was determined using the OIM method (orientation imaging microscopy). Determination of chromium concentration in solution was carried out by the atomic absorption spectroscopy (AAS). The anodic and cathodic polarization curves were recorded, and also, electrochemical corrosion rates were determined using the various electrochemical methods.

\section{EXPERIMENTAL PART}

Before testing, the surface of chromium samples was mechanically polished gradually with abrasive paper to the grade 1000 . The solution for testing was $0.1 \mathrm{M} \mathrm{Na}_{2} \mathrm{SO}_{4}+$ $\mathrm{H}_{2} \mathrm{SO}_{4}$, $\mathrm{pH} 1$, which was purified conducting through testing solution of pure nitrogen.

A three-part glass electrochemical cell with water jackets for thermostationing, with an auxiliary $\mathrm{Pt}$ electrode and a saturated calomel electrode (SCE) as the reference electrode were used for electrochemical tests.

The chromium electrode was cathodically activated at $-0.900 \mathrm{~V}$ for $120 \mathrm{~s}$ to the aim of removal thesurface oxide layer before each test. Oxide layer is spontaneously cre

\footnotetext{
* Institute for Chemistry, Technology and Metallurgy, IHTM, University of Belgrade, Njegoševa 12, Belgrade, Serbia,E-mail: borejegdic@yahoo.com

*** The work was funded by the Ministry of Education and Science and Technological Development of the Republic of Serbia, Project No. 34028.
} 
ates on the chromium surface in contact with air. Electrochemical measurements were made using the potentiostat-galvanostat PAR 273.

\section{RESULTS AND DISCUSION}

Figure 1 shows the inverse polar image of chromium, obtained by the OIM method.

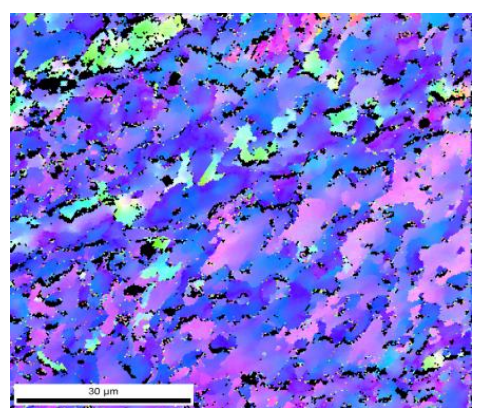

The grains with the orientation (111) are marked with blue colour and it can be seen that a large number of grains on the chromium surface has exactly this orientation. The size of chromium crystal grains was also determined, which have been the small dimensions, with a high degree of in orientations. In fact, these are separate grains with their own orientation.

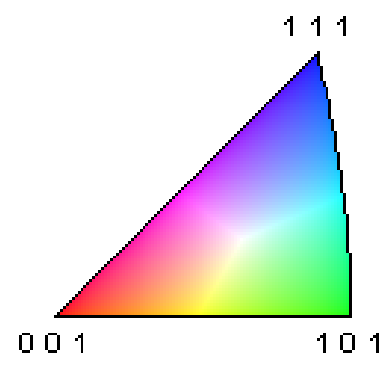

Figure 1 Texture (111) of the chromium electrode is obtained by the OIM method. The approximate grain size can be estimated on the basis of the scale given in Figure

The temperature influence on chemical and electrochemical chromium dissolution in temperature the range from 291 to $353 \mathrm{~K}$ in aqueous sulphuric acid, $\mathrm{pH} 1$ was carried out.

Cathodic polarization curves, recorded at different temperatures at 291 to $343 \mathrm{~K}$ in sulphuric acid pH 1, are shown in Figure 2. Figure 2 shows that with an increase in temperature, the rate of hydrogen evolution in creases, while the Tafel slope variation with the temperature was at theoretically expected levels. An inset in Figure 2 shows the dependence of current density logarithm as a function of reciprocal temperature for determination the apparent activation energy for hydrogen evolution at $-0.860 \mathrm{~V}$. The apparent activation energy $35 \mathrm{~kJ} \mathrm{~mol}^{-1}$ is for cathodic reaction of hydrogen evolution.

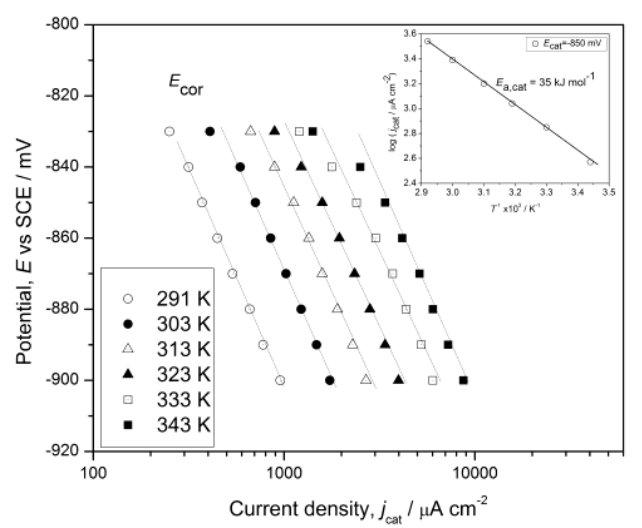

Figure 2 Chatodic polarization curves for chromium electrode in aqueous solution of $0.1 \mathrm{M} \mathrm{Na}_{2} \mathrm{SO}_{4}+\mathrm{H}_{2} \mathrm{SO}_{4}, \mathrm{pH} 1$ at various temperatures 
The anodic polarization curves of chromium in the solution of sodium sulphate and sulphuric acid $\mathrm{pH} 1$, recorded at different temperatures, were shown Figure 3. The shape of polarization curves is similar, except that the curves at higher temperatures are shifted towards higher current densities, as it might be expected. The Arrhenius dependence at $-0.750 \mathrm{~V}$ is shown in inset in Figure 3. The apparent activation energy $E_{\mathrm{a}, \text { an }}=58 \mathrm{~kJ} \mathrm{~mol}^{-1}$ obtained for the reaction of the active anodic dissolution. This indicates that the anodic reaction is more dependent on temperature than the cathodic reaction. The corrosion potential change with temperature in a direction of more negative potentials also explains this.

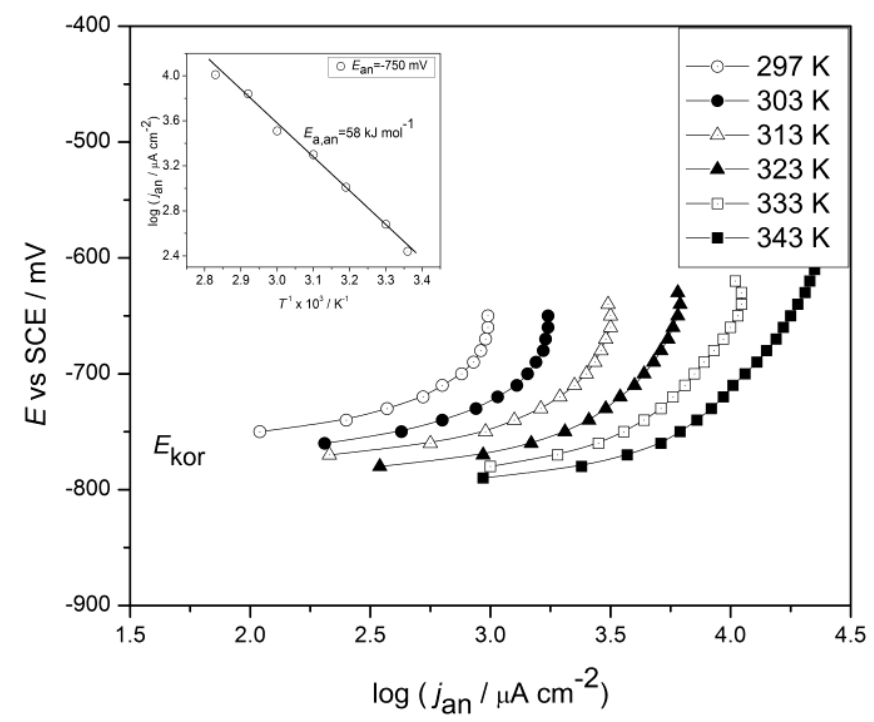

Figure 3 Anodic polarization curves of chromium electrode in sulphuric acid solution $\mathrm{pH} 1$, at various temperatures

The electrochemical current density $j_{\text {corel }}$ is determined by extrapolation the Tafel slope on corrosion potential and by the Stern-Gery linear polarization method, while the total chromium dissolution rate $j_{\text {tot }}$, was determined analyzing the solution with atomic absorption spectrophotometry, and they are shown in Figure 4. It can be seen from Figure 4 that the overall rate of dissolution or equivalent current density with temperature is higher than the electro chemical corrosion current density. A significant part of electrochemical corrosion is the chemical corrosion of chromium at all temperatures. That difference increases with temperature as it can be seen in Figure 4. At $353 \mathrm{~K}$, the total dissolution rate is about four times higher than the electrochemical corrosion rate. It means that the chemical dissolution rate at this temperature is for approximately three times higher than the electrochemical dissolution rate. 


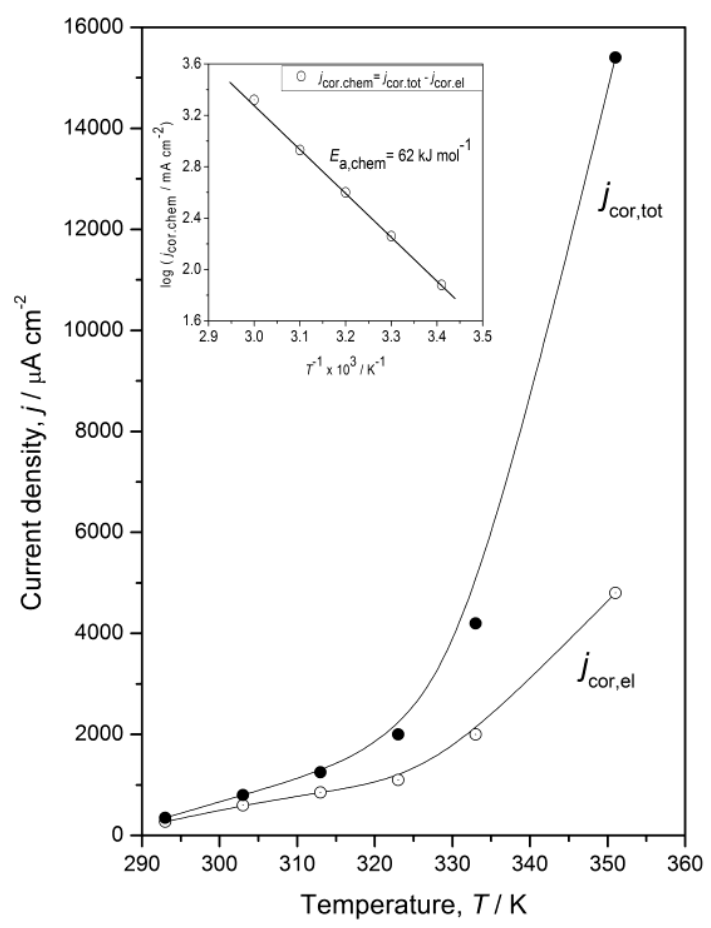

Figure 4 Total current density obtained analytically $(\bullet)$ and corrosion current density obtained electrochemically at different temperatures (०) for the chromium electrode

As it is shown in Figure 4, the overall corrosion rate $j_{\text {tot }}$ at all temperatures that are used in this experiment are higher than the electrochemical corrosion rates $j_{\text {cor,el }}$. This is the result of chemical dissolution of chromium, which takes place directly by reaction of water molecules and atoms of chromium from the electrode surface and not dependent on potentials. Differences between the total chromium dissolution rate determined analytically $j_{\text {tot,anal }}$ and electrochemical dissolution rate $j_{\text {cor,el }}$ vs. the reciprocal temperature is plotted on the inset in Figure 4. The apparent activation energy was determined from the slope of this linear dependence and it is $62 \mathrm{~kJ} \mathrm{~mol}^{-1}$. The high value of activation energy indicate that the influence of temperature on reaction of chemical dissolution is large and that contribution of chemical corrosion to the overall corrosion rate is higher at the elevated than the lower temperatures. This should be kept in mind if using data for corrosion rate, obtained at room temperature, for predicting the corrosion behaviour at elevated temperatures. The similar differences in terms of temperature influence likely existing in case of corrosion of other metals that corrode electrochemically and chemically (i.e., $\mathrm{Fe}, \mathrm{Ni}, \mathrm{Mn}$ and other metals).

After immersion into testing solution, the chromium electrode is in a passive state with the characteristic corrosion potential $E_{\mathrm{cor}, 1}$. During the cathodic polarization at $-0.900 \mathrm{~V}$, for several tens of seconds, the passive films are dissolved, whereby the electrodes activated and the corrosion potential $E_{\mathrm{cor}, 2}$ is then formed.

The chatodic curves recorded on passive chromium in form of the Tafel dia 
grams for different temperatures are presented in Figure 5. It can be noted that cathodic Tafel slope is approximately $-0.060 \mathrm{~V} \mathrm{dec}^{-1}$ and that the current density increases with temperature. The inset in Figure 5 shows the Arrhenius dependence, obtained at $-0.520 \mathrm{~V}$. The apparent activation energy was determined, that is $29 \mathrm{~kJ} \mathrm{~mol}^{-1}$. Slightly lower value of activation energy is than obtained in the process of hydrogen evaluation on the activated chromium surface $\left(35 \mathrm{~kJ} \mathrm{~mol}^{-1}\right)$.

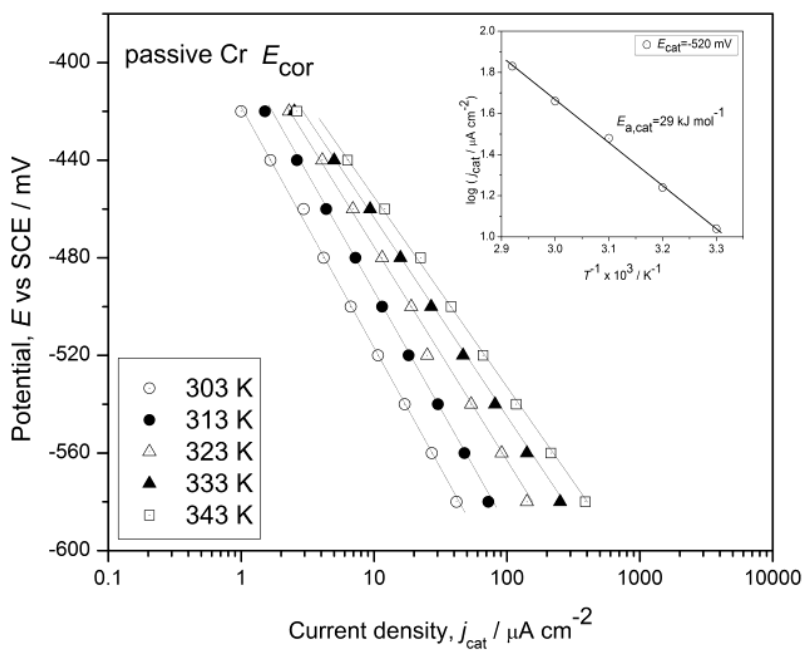

Figure 5 The chatodic Tafel plots for passivated chromium electrode at different temperature

Accordingly, the corrosion of active metallic chromium in an aqueous solution of sulphuric acid $\mathrm{pH} 1$ consists of two simultaneous processes corrosion, the electrochemical corrosion and chemical dissolution. With increase of temperate, significantly increases the anodic dissolution, chemical dissolution, and cathodic hydrogen evolution on the bare chromium surface, as well as on the surface coated with chromium oxide in $0.1 \mathrm{M} \mathrm{Na}_{2} \mathrm{SO}_{4}+\mathrm{H}_{2} \mathrm{SO}_{4}$ solution, $\mathrm{pH} 1$.

Reaction of the hydrogen evolution, anodic dissolution and chemical dissolution on the activated chromium surface in sulp-huric acid solution, $\mathrm{pH} 1$ in temperature range of 293 to $353 \mathrm{~K}$ followed the Arrhe-nius dependence with an apparent activation energy of $35 \mathrm{~kJ} \mathrm{~mol}^{-1} .58 \mathrm{~kJ} \mathrm{~mol}^{-1}$ and $62 \mathrm{~kJ} \mathrm{~mol}^{-1}$, respectively. The apparent activation energy of the hydrogen evolution reaction on chro- mium oxide covered surface has value of $29 \mathrm{~kJ} \mathrm{~mol}^{-1}$.

\section{CONCLUSION}

Corrosion of the active metallic chromium in aqueous sulphuric acid $\mathrm{pH} 1$ simultaneously flowed by electrochemical and chemical mechanism. The rate of che-mical corrosion is obtained as difference of the total and electrochemical corrosion rate.

Reaction of the hydrogen evolution, anodic dissolution and chemical dissolution of $\mathrm{Cr}$ from chromium-activated surface in sulphuric acid solution, $\mathrm{pH} 1$ at temperature from 291 to $353 \mathrm{~K}$ followed the Arrhenius law from the apparent activation energy of $35 \mathrm{~kJ} \mathrm{~mol}^{-1}, 58 \mathrm{~kJ} \mathrm{~mol}^{-1}$ and $62 \mathrm{~kJ} \mathrm{~mol}^{-1}$, respectively. A high activation energy of chemical dissolution of chromium, at ele 
vated temperatures causes to significantly higher chemical corrosion, compared to electrochemical corrosion. The apparent activation energy of hydrogen evolution on the chromium-covered oxide layer has a value of $29 \mathrm{~kJ} \mathrm{~mol}^{-1}$.

As the result of simultaneous occurrence of reaction of hydrogen evolution on the oxide-covered chromium surface and reaction of anodic dissolution of chromium through the passive film, the stable corrosion potential $E_{\text {cor.1 }}$ was formed. The other corrosion potential was formed as the results of cathodic hydrogen evolution and anodic dissolution on the bare chromium surfaces, when the chromium surface is depasivated (by cathodic activation, or mechanical action, etc.). In this case, the stable corrosion potential $E_{\text {cor.2 }}$ establishes.

\section{REFERENCES}

[1] Wilde B. E., Hodge F. G., The Cathodic Discharge of Hydrogen on Active and Passive Chromium Surfaces in Dilute Sulphuric Acid Solutions, Electrochim. Acta 14 (7) (1969) pp. 619627;

[2] Kolotyrkin Ya. M., Florianovich G. M., Anomalnoe rastvorenie metallov. Eksperimentalnie fakti i ih teoreticheskoe tolkovanie, Zashch. Metal. 20 (1) (1984) pp. 14-24;

[3] Dražić D. M., Popić J. P., Anomalous Dissolution of Metals and Chemical Corrosion (Review), J. Serb. Chem. Soc. 70 (3) (2005) pp. 489-513;

[4] Dražić D. M., Popić J. P., Dissolution of Chromium in Sulfuric Acid, J. Serb. Chem. Soc. 67 (11) (2002) pp. 777-783;

[5] Popić J. P., Dražić D. M., Electrochemistry of Active Chromium. Part III.
Effect of Temperature, J. Serb. Chem. Soc. 68 (11) (2003) pp. 871-883;

[6] Dražić D. M., Popić J. P., Electrochemistry of Active Chromium: Part 1-Anomalous Corrosion and Products of Chromium Dissolution in Deaerated Sulfuric Acid, Corrosion 60 (3) (2004) pp. 297-304.

[7] Popić J. P., Dražić D. M., Electrochemistry of Active Chromium: Part II. Three Hydrogen Evolution Reactions on Chromium in Sulfuric Acid, Electrochim. Acta 49 (27) (2004) pp. 4877-4891;

[8] Dražić D. M., Popić J. P., Jegdić B., Vasiljević-Radović D., Electrochemistry of Active Chromium. Part IV. Dissolution of Chromium in Deaerated Sulfuric Acid, J. Serb. Chem. Soc. 69 (12) (2004) pp. 1099-1110;

[9] Sukhotin A. M., Khoreva N. K., Passivnost khroma. Osobenosti katodnogo aktivirovaniya khroma, Electrokhimiya 18 (1) (1982) pp. 132-134;

[10] Jegdić B., Dražić D. M., Popić J. P., Structural Effects of Metallic Chromium on its Electrochemical Behavior, J. Serb. Chem. Soc. 72 (6) (2007) pp. 563-578;

[11] Jegdić B., Dražić D. M., Popić J. P., Influence of Chloride Ions on the Open Circuit Potentials of Chromium in Deaerated Sulfuric Acid Solutions, J. Serb. Chem. Soc. 71 (11) (2006) pp. 1187-1194;

[12] Jegdić B., Dražić D. M., Popić J. P., Open Circuit Potentials of Metallic Chromium And Austenitic 304 Stainless Steel in Aqueous Sulphuric Acid Solution and the Influence of Chloride Ions on them, Corr. Sci. 50 (2008) pp. 1235-1244. 


\begin{tabular}{ll}
\hline \hline INSTITUT ZA RUDARSTVO I METALURGIJU BOR & ISSN: 2334-8836 (Štampano izdanje) \\
UDK: 622 & ISSN: 2406-1395 (Online) \\
\hline \hline
\end{tabular}

\section{HEMIJSKO I ELEKTROHEMIJSKO RASTVARANJE HROMA NA SOBNOJ I NA POVIŠENIM TEMPERATURAMA**}

\section{Izvod}

Ispitivan je uticaj temperature na elektrohemijsko i hemijsko rastvaranje hroma u kiselim rastvorima sulfata. Reakcije izdvajanja vodonika, anodnog rastvaranja i hemijskog rastvaranja hroma sa aktivirane površine hroma u rastvoru sumporne kiseline $\mathrm{pH} 1$ slede Arenijusovu zavisnost sa prividnom energijom aktivacije $35 \mathrm{~kJ} \mathrm{~mol}^{-1}$, $58 \mathrm{~kJ} \mathrm{~mol}^{-1}$ i $62 \mathrm{~kJ} \mathrm{~mol}^{-1}$, respektivno. Velika energija aktivacije hemijskog rastvaranja hroma dovodi na povišenim temperaturama do znatno izraženije hemijske korozije u odnosu na elektrohemijsku koroziju.

Ključne reči: hemijska korozija hroma, elektrohemijsko rastvaranje, prividna energija aktivacije

\section{UVOD}

Paralelno sa elektrohemijskim rastvaranjem hroma odvija i njegovo hemijsko rastvaranje, koje ne zavisi od potencijala i koje je u nekim uslovima dominantan proces rastvaranja, naročito na povišenim temperaturama [1-9]. Hemijsko rastvaranje hroma je uzrok pojavi izdvajanja vodonika, koje ne podleže zakonitostima elektrohemijske kinetike.

U ovom radu vršeno je određivanje energije aktivacije procesa hemijskog rastvaranja hroma, elektrohemijskog rastvaranja hroma, katodnog izdvajanja vodonika i temperaturne zavisnosti brzine elektrohemijske korozije. Takođe, određena je teksture hroma primenom OIM metode (orientation imaging microscopy). Određivanje koncentracije hroma u rastvoru je vršeno primenom atomske apsorpcione spektroskopije (AAS). Vršeno je snimanje anodnih i katodnih polarizacionih krivih i određi- vanje brzine elektrohemijske korozije primenom različitih elektrohemijskih metoda.

\section{EKSPERIMENTALNI DEO}

Pre ispitivanja, površina uzoraka hroma je mehanički polirana stupnjevito brusnim papirom do finoće 1000 . Rastvor za ispitivanje je bio $0,1 \mathrm{M} \mathrm{Na}_{2} \mathrm{SO}_{4}+\mathrm{H}_{2} \mathrm{SO}_{4}, \mathrm{pH}$, koji je deaerisan provođenjem prečišćenog azota. Za izvođenje elektrohemijskih ispitivanja korišćena je trodelna staklena elektrohemijska ćelija sa vodenim plaštom za termostatiranje, sa Pt pomoćnom elektrodom i zasićenom kalomelovom elektrodom (ZKE) kao referentnom elektrodom.

Pre merenja, elektroda hroma je aktivirana katodnom polarizcijom na $-0,900 \mathrm{~V}$ tokom $120 \mathrm{~s}$ radi uklanjanja površinskog oksida, koji se na hromu uvek spontano stvara u dodiru sa vazduhom. Elektro-

\footnotetext{
*NU Institut za hemiju tehnologiju i metalurgiju, IHTM, Univerzitet u Beogradu, Njegoševa 12, Beograd,Srbija,e-mail:borejegdic@yahoo.com

** Ovaj rad je finansiran od strane Ministarstva prosvete, nauke i tehnološkog razvoja Republike Srbije, Projekat No. 34028.
} 
hemijska merenja su izvedena primenom potenciostata-galvanostata PAR 273.

\section{REZULTATI I DISKUSIJA}

Na slici 1 je prikazana inverzna polarna slika uzorka hroma dobijena OIM metodom.
Plavom bojom je označena orijentacija zrna (111) i vidi se da veliki broj zrna na površini elektrode ima upravo tu orijentaciju. Takođe određena je veličina kristalnih zrna, koja su bila malih dimenzija sa velikim stepenom razorijentisanosti. Zapravo, to su zasebna zrna sa sopstvenom orijentacijom.
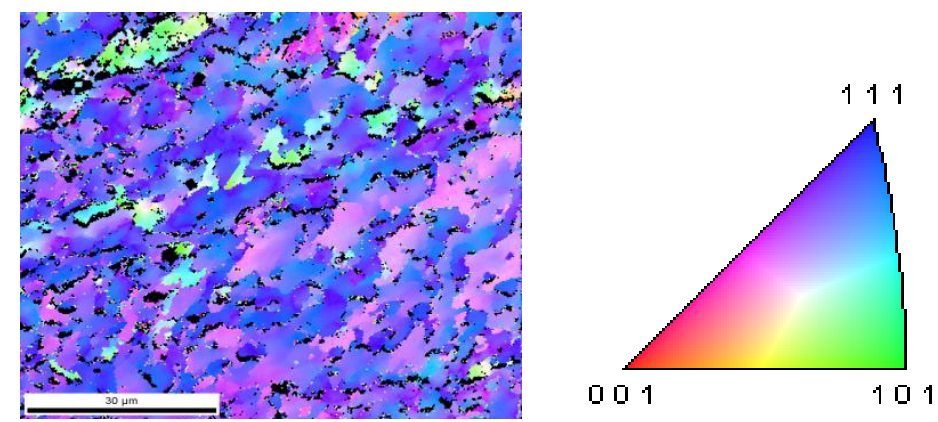

SI. 1. Inverzna polarna slika, tekstura (111) elektrode hroma dobijena OIM metodom. Orijentaciona veličina zrna se može proceniti na osnovu razmere date na slici

Ispitivan je uticaj temperature na hemijsko i elektrohemijsko rastvaranje elektrode $\mathrm{Cr}$ u temperaturnom intervalu od 291 do $353 \mathrm{~K} \mathrm{u}$ vodenom rastvoru sumporne kiseline, $\mathrm{pH} 1$.

Katodne polarizacione krive snimljene na različitim temperaturama iz oblasti od 291 do $343 \mathrm{~K}$ u sumpornoj kiselini pH 1 su prikazane na slici 2 . Sa slike se vidi da se sa povećanjem temperature povećava brzina izdvajanja vodonika, pri čemu je varijacija Tafelovih nagiba sa temperaturom bila $u$ teoretski očekivanim okvirima. Isečak na slici 2 prikazuje zavisnost logaritma gustine struje kao funkcije recipročne temperature, za određivanje prividne energije aktivacije, za reakciju izdvajanja vodonika na $-0,860$ V. Prividna energija aktivacije za reakciju katodnog izdvajanja vodonika je $35 \mathrm{~kJ} \mathrm{~mol}^{-1}$.

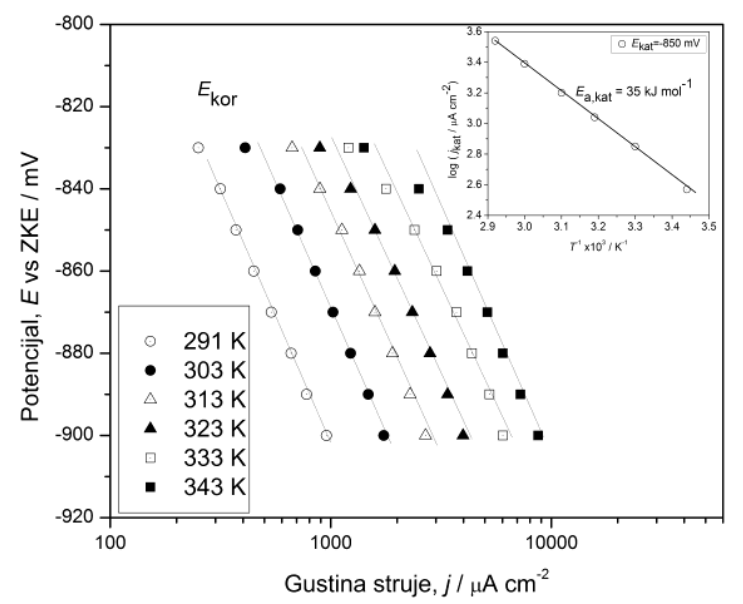

S1. 2. Katodne polarizacione krive za elektrodu hroma u vodenom rastvoru 0,1 $\mathrm{M} \mathrm{Na}_{2} \mathrm{SO}_{4}+\mathrm{H}_{2} \mathrm{SO}_{4}$, pH 1 na razlicitim temperaturama 
$\mathrm{Na}$ slici 3 su prikazane krive anodne polarizacije hroma $\mathrm{u}$ rastvoru natrijumsulfata i sumporne kiseline pH 1 snimljene na različitim temperaturama. Oblik polarizacionih krivih je sličan izuzev što su krive na većim temperaturama pomerene prema većim gustinama struje, kao što se moglo i očekivati. Arenijusova zavisnost za $-0,750 \mathrm{~V}$ prikazana na isečku na slici 3 daje prividnu energiju aktivacije za reakciju aktivnog anodnog rastvaranja od $E_{\mathrm{a}, \text { an }}=58 \mathrm{~kJ} \mathrm{~mol}^{-1}$. To ukazuje da anodna reakcija više zavisi od temperature nego katodna reakcija, što takođe objašnjava promenu korozionog potencijala sa temperaturom u smeru negativnijih potencijala.

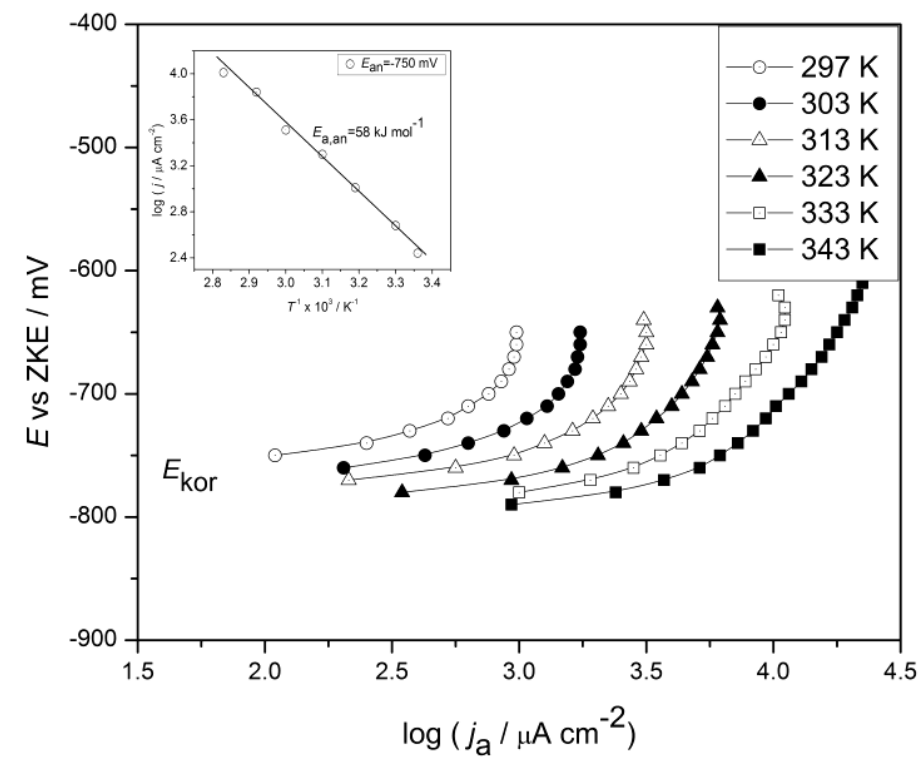

SI. 3. Anodne polarizacione krive za elektrodu hroma u rastvoru sumporne kiseline $\mathrm{pH} 1$ na različitim temperaturama

Gustina struje elektrohemijske korozije $j_{\text {kor,el }}$ je određivana ekstrapolacijom Tafelovih nagiba na korozioni potencijal i SternGerievom metodom linearne polarizacije, dok je ukupna brzina rastvaranja određivana analizom rastvora primenom atomske apsorpcione spektrofotometrije $j_{\text {uk,an }}$, i prikazane su na slici 4. Sa slike 4 se može videti da je ukupna brzina rastvaranja, odnosno ekvivalentna gustina struje za sve temperature veća nego gustina struje elektrohemijskog rastva- ranja tj. elektrohemijske korozije. To pokazuje da postoji pored elektrohemijskog značajno hemijsko rastvaranje hroma na svim temperaturama. Ta razlika se povećava sa povećanjem temperature kao što se može videti sa slike 4 . Na $353 \mathrm{~K}$ ukupna brzina rastvaranja je približno četiri puta veća nego elektrohemijska brzina korozije. $\mathrm{U}$ isto vreme to znači da je brzina hemijskog rastvaranja na toj temperaturi približno tri puta veća nego brzina elektrohemijskog rastvaranja. 


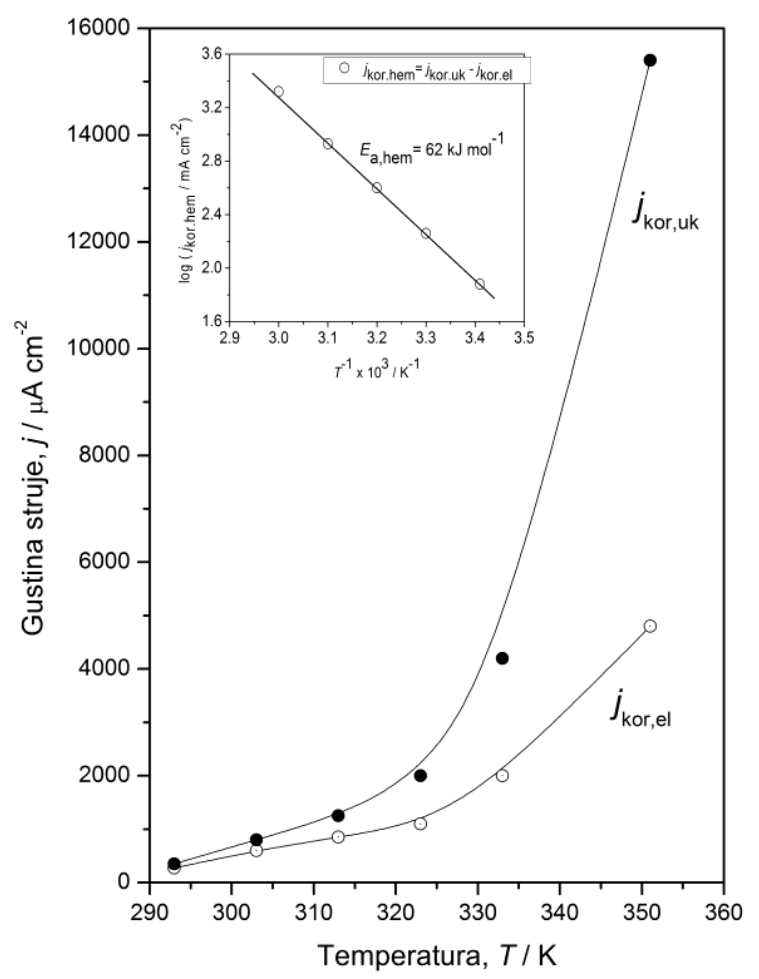

Sl. 4. Ukupna gustina struje dobijena analitički (•) i gustina korozione struje dobijena elektrohemijski na razlicitim temperaturama (০) za elektrodu hroma

Kao što je prikazano na slici 4, ukupne brzine korozije $j_{\mathrm{uk}}$ na svim temperaturama koje su korišćene pri ovim eksperimentima su veće nego elektrohemijske brzine korozije $j_{\text {kor,el. }}$ Ta razlika je posledica hemijskog rastvaranja hroma, koji se odvija direktnom rekcijom molekula vode $\mathrm{i}$ atoma hroma sa površine elektrode i koji ne zavisi od potencijala. Razlike između ukupne brzine rastvaranja određene analitički $j_{\text {uk,anal }} i$ elektrohemijskih brzina korozije $j_{\text {kor,el }}$ su nacrtane u zavisnosti od recipročne vrednosti temperature na isečku na slici 4 . Iz nagiba te pravolinijske zavisnosti se može odrediti prividna energija aktivacije $\mathrm{i}$ ona iznosi $62 \mathrm{~kJ} \mathrm{~mol}^{-1}$. Visoka vrednost energije aktivacije ukazuje da je uticaj temperature na reakciju hemijskog rastvaranja prilično velik i da je doprinos ukupnoj brzini korozije veći u oblasti povišenih nego nižih temperatura. To treba imati u vidu kada se koriste podaci o brzini korozije dobijeni na sobnoj temperaturi za predviđanje korozionog ponašanja na povišenim temperaturama. Vrlo je moguće da slične razlike u pogledu uticaja temperature postoje u slučaju korozije ostalih metala koji korodiraju i elektrohemijski i hemijski (tj. Fe, Ni, Mn i drugi).

Hrom se nalazi u pasivnom stanju posle uranjanja u rastvor za ispitivanje, sa karakterističnim korozionim potencijalom $E_{\mathrm{kor}, 1}$ koji odgovara pasivnom stanju hroma. Tek katodnom polarizacijom na $-0,900 \mathrm{~V}$ u toku nekoliko desetina sekundi, pasivni films se rastvara, pri čemu se elektroda aktivira. Tada se formira korozioni potencijal $E_{\mathrm{kor}, 2}$ koji odgovara aktivnom hromu.

Katodne krive snimljene na pasiviranom hromu, prikazane u obliku Tafelovog dijagrama za različite temperature predstavljene 
su na slici 5. Uočava se da je katodni Tafelov nagib približno jednak $-0,060 \mathrm{~V} \mathrm{dek}^{-1} \mathrm{i}$ da se gustina struje povećava sa temperaturom. Isečak na slici 5 predstavlja Arenijusov dijagram dobijen na $-0,520 \mathrm{~V}$ sa koga se može odrediti prividna energija aktivacije koja iznosi $29 \mathrm{~kJ} \mathrm{~mol}^{-1}$. To je nešto manja vrednost nego energija aktivacije za izdvajanje vodonika na aktiviranoj površini hroma $\left(35 \mathrm{~kJ} \mathrm{~mol}^{-1}\right)$

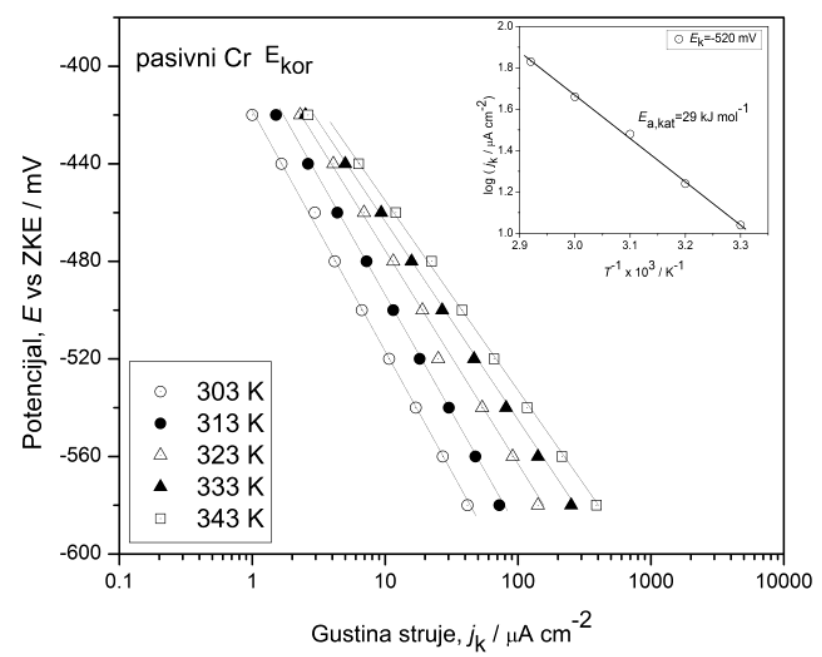

SI. 5. Katodne Tafelove zavisnosti za pasiviranu elektrodu B sa slike 4.29. na različitim temperaturama

Prema tome korozija aktivnog metalnog hroma u vodenom rastvoru sumporne kiseline $\mathrm{pH} 1$ se sastoji od dva simultana koroziona procesa, elektrohemijske korozije i hemijskog rastvaranja. Pokazano je da se na $\mathrm{Cr}$ elektrodi u rastvoru $0,1 \mathrm{M} \mathrm{Na} \mathrm{SO}_{4}+$ $\mathrm{H}_{2} \mathrm{SO}_{4}, \mathrm{pH} 1$ sa povišenjem temperature značajno ubrzavaju reakcije anodnog rastvaranja hroma, hemijskog rastvaranja hroma, katodnog izdvajanja vodonika na čistoj metalnoj površini, kao i na površini hroma prevučenoj oksidom.

Reakcija izdvajanja vodonika, reakcija anodnog rastvaranja i reakcija hemijskog rastvaranja hroma sa aktivirane površine $\mathrm{u}$ rastvoru sumporne kiseline $\mathrm{pH} 1 \mathrm{u}$ temperaturskom intervalu od 293 do $353 \mathrm{~K}$ slede Arenijusovu zavisnost sa prividnom energijom aktivacije $35 \mathrm{~kJ} \mathrm{~mol}^{-1}, 58 \mathrm{~kJ} \mathrm{~mol}^{-1} \mathrm{i}$ $62 \mathrm{~kJ} \mathrm{~mol}^{-1}$, respektivno. Prividna energija akti-vacije reakcije izdvajanja vodonika na hromu prekrivenom oksidom ima vrednost $29 \mathrm{~kJ} \mathrm{~mol}^{-1}$.

\section{ZAKLJUČAK}

Korozija aktivnog metalnog hroma $\mathrm{u}$ vodenom rastvoru sumporne kiseline $\mathrm{pH} 1$ se odvija paralelno elektrohemijskim i hemijskim mehanizmom. Brzina hemijske korozije se dobija iz razlika ukupne i elektrohemijske brzine korozije.

Reakcija izdvajanja vodonika, reakcija anodnog rastvaranja i reakcija hemijskog rastvaranja $\mathrm{Cr}$ sa aktivirane površine u rastvoru sumporne kiseline $\mathrm{pH} 1 \mathrm{u}$ temperaturnom intervalu od 291 do $353 \mathrm{~K}$ slede Arenijusovu zavisnost sa prividnom energijom aktivacije $35 \mathrm{~kJ} \mathrm{~mol}^{-1}, 58 \mathrm{~kJ} \mathrm{~mol}^{-1}$ i $62 \mathrm{~kJ}$ $\mathrm{mol}^{-1}$, respektivno. Velika energija aktivacije hemijskog rastvaranja hroma dovodi na povišenim temperaturama do znatno izra- 
ženije hemijske korozije $u$ odnosu na elektrohemijsku koroziju. Prividna energija aktivacije reakcije izdvajanja vodonika na hromu prekrivenom oksidnim filmom ima vrednost $29 \mathrm{~kJ} \mathrm{~mol}^{-1}$.

Korozioni potencijal je posledica simultanog odvijanja reakcije izdvajanja vodonika bilo na oksidom prekrivenoj površini hroma sa reakcijom anodnog rastvaranja hroma kroz pasivni film obrazujući stabilni potencijal $E_{\text {kor.1 }}$ ili katodnim izdvajanjem vodonika i anodnim rastvaranjem ogoljene površine kada se površina hroma depasivira na neki način (katodnom aktivacijom, mehaničkim delovanjem itd.). U tom slučaju uspostavlja se stabilni korozioni potencijal $E_{\text {kor.2. }}$.

\section{LITERATURA}

[1] Wilde B. E., Hodge F. G., The cathodic discharge of hydrogen on active and passive chromium surfaces in dilute sulphuric acid solutions, Electrochim. Acta 14 (7) (1969) pp. 619-627.

[2] Kolotyrkin Ya. M., Florianovich G. M., Anomalnoe rastvorenie metallov. Eksperimentalnie fakti i ih teoreticheskoe tolkovanie, Zashch. Metal. 20 (1) (1984) pp. 14-24

[3] Dražić D. M., Popić J. P., Anomalous dissolution of metals and chemical corrosion (Review), J. Serb. Chem. Soc. 70 (3) (2005) pp. 489-513.

[4] Dražić D. M., Popić J. P., Dissolution of chromium in sulfuric acid, J. Serb. Chem. Soc. 67 (11) (2002) pp. 777-783.

[5] Popić J. P., Dražić D. M., Electrochemistry of active chromium. Part III. Effect of temperature, J. Serb. Chem. Soc. 68 (11) (2003) pp. 871-883.
[6] Dražić D. M., Popić J. P., Electrochemistry of Active Chromium: Part 1Anomalous Corrosion and Products of Chromium Dissolution in Deaerated Sulfuric Acid, Corrosion 60 (3) (2004) pp. 297-304.

[7] Popić J. P., Dražić D. M., Electrochemistry of active chromium: Part II. Three hydrogen evolution reactions on chromium in sulfuric acid, Electrochim. Acta 49 (27) (2004) pp. $4877-$ 4891.

[8] Dražić D. M., Popić J. P., Jegdić B., Vasiljević-Radović D., Electrochemistry of active chromium. Part IV. Dissolution of chromium in deaerated sulfuric acid, J. Serb. Chem. Soc. 69 (12) (2004) pp. 1099-1110.

[9] Sukhotin A. M., Khoreva N. K., Passivnost khroma. Osobenosti katodnogo aktivirovaniya khroma, Electrokhimiya 18 (1) (1982) pp. 132-134.

[10] Jegdić B., Dražić D. M., Popić J. P., Structural effects of metallic chromium on its electrochemical behavior, J. Serb. Chem. Soc. 72 (6) (2007) pp. 563-578.

[11] Jegdić B., Dražić D. M., Popić J. P., Influence of chloride ions on the open circuit potentials of chromium in deaerated sulfuric acid solutions, J. Serb. Chem. Soc. 71 (11) (2006) pp. 11871194.

[12] Jegdić B., Dražić D.M., Popić J. P., Open circuit potentials of metallic chromium and austenitic 304 stainless steel in aqueous sulphuric acid solution and the influence of chloride ions on them, Corr. Sci. 50 (2008) pp. 12351244. 